\title{
Is DEVELOPMENT A Lost PARAdise? TRADE, ENVIRONMENT, AND DEVELOPMENT: A TRIADIC DREAM OF INTERNATIONAL LAW
}

\author{
UPENDRA D. ACHARYA*
}

\begin{abstract}
After providing a briefbackground on international law, the history of the right to development is discussed. International law, as it exists today, has been abused by developed nations in their position of power over underdeveloped nations. The right to development, first formalized by the United Nations in 1986 with the Declaration on the Right to Development, was meant to give people of the developing world a right to development. However, the right to development has been supplanted by the concept of sustainable development, as orchestrated by the developed nations. It was hopeful that organizations like the World Trade Organization would implement the right to development through trade; however, these organizations have become merely a tool for the developed nations and associated corporations to continue their dominance over developing nations. Environmental concerns in recent times have shifted the international focus from the right to development to sustainable development, and the right to development has been overlooked. A legal right to development must be recognized before sustainable development can be applied as a tool to benefit underdeveloped nations through environmental and trade-related policy.
\end{abstract}

Après avoir donné une courte mise en situation sur le droit international, l'histoire du droit au développement y est discutée. Le droit international, tel qu'il existe aujourd'hui, a été abusé par les pays développés, notamment dans leur position de pouvoir sur les pays sous-développés. Le droit au développement, formalisé pour la première fois par les Nations-Unies en 1986 avec la Déclaration sur le droit au développement, devait donner, aux peuples des pays en voie de développement, le droit au développement. Cependant, le concept de développement durable, orchestré par les pays développés, est venu supplanter ce droit au développement. On avait espéré que des organismes comme l'Organisation mondiale du commerce aurait mis en place le droit au développement dans le cadre du commerce. Cependant, ces organismes sont devenus de simples outils pour les pays développés et leurs corporations associées pour continuer à exercer leur domination sur les pays en voie de développement. Compte tenu des récentes préoccupations d'ordre environnemental, les intérêts internationaux sont passés du droit au développement au développement durable, et on a fait abstraction du droit au développement. Il faut reconnaître le droit légal au développement avant de pouvoir appliquer le développement durable en tant qu'outil pour que les pays sous-développés puissent profiter de politiques liées à l'environnement et au commerce.

\section{TABLE OF CONTENTS}

I. INTRODUCTION . . . . . . . . . . . . . . . . . . . . . . 402

II. INTERNATIONAL LAW - DiFFERENT PERCEPTIONS . . . . . . . . . . . . . 402

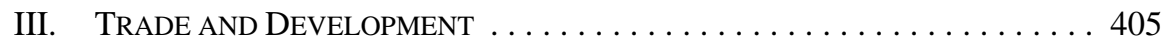

IV. ENVIRONMENT AND DEVELOPMENT . . . . . . . . . . . . . . . 410

V. Is THERE ANy Right to DeVELOPMENT LEFT? . . . . . . . . . . . . . . . 415

Assistant Professor of Law, Gonzaga University School of Law; LL.B. Nepal Law Campus; M.C.L. University of Delhi, College of Law; LL.M. University of Utah, College of Law; S.J.D. University of Wisconsin, Madison Law School. The author would like to acknowledge and express his appreciation to the many colleagues and friends whose support and suggestions have been so valuable to this article. Special thanks to Jeannie Young and Frank J. Garcia for their insightful suggestions. Earlier drafts of this article were delivered at the Symposium. The author would like to thank the participants at the presentation for their helpful suggestions. 


\section{INTRODUCTION}

International law deals with the relationship among countries and between international organizations and countries. As an organic and dynamic concept, international law addresses issues of peace and security, development, human rights, global environmental problems, and other issues of international concern. Its purpose is to benefit countries in their political, economic, and environmental affairs, thereby promoting a state of world peace where all peoples and countries will be respected and dignified. Unfortunately, we do not live in such a utopia.

Throughout recorded history, societies have been afflicted with inequalities among peoples and countries, violence, war, the greed of powerful nations, gross violations of human rights, and so on. However, the international community, in response to experiencing such tragic events and behaviors by its members, has begun addressing these issues through international law. In the process, international law has at times been used as a tool to legitimize the actions of the victors and the powerful. Unjustified use or forceful justification of international law has created more problems than resolutions. The heart of such problems is the use and abuse of international law by western countries, with developing countries relegated to the role of observers. It is not that the developing world is not interested in international law, but rather that it does not possess the same academic and financial strength as the western countries. The root of this inequality lies at the level of development. Disparate levels of development are a core cause of the bitter events that have challenged societies at present and historically. This article will focus on the development issue, arguing that the concept of development has been made to disappear in the trade and environment debate. While discussing the role of perception of international law as it relates to international efforts of development, I put forth the notion that development as a right, with sustainable development as a practice style or discipline of that right, has been lost in the name of sustainable development. Whereas development is an ultimate goal of human beings (therefore a substantive right), sustainable development is a tool to realize fairness and justice to the present and future generations (therefore a procedural limitation to the substantive right).

\section{International LAW — DifFERENT PERCEPTIONS}

International law has been perceived differently by the developed and developing world. Because international law evolved in the western hemisphere, western countries perceive themselves as having a proprietary right in the concept and consequently claim authority over the subject matter. This perception is well supported by resourceful western academics and the strength of western media; ${ }^{1}$ at the same time, the poor South is still struggling to understand

Here I assume that western countries have controlled both the substance of international law, which is founded on western principles, as well as the processes by which it developed. Most western international law pundits root their analyses in natural law theory and positive theory, as described by Francisco de Vitoria, Francisco Suárez, Hugo Grotius, Christian von Wolff, and Emerich de Vattel. Their work is furthered by modern scholars such as J.L. Brierly, Lass Francis Lawrence Oppenheim, H.L.A. Hart, and Martti Koskenniemi, among others. Even progressive scholars are unwilling to approach international law from anything other than a perspective grounded in European history and thought (pre-feudal, feudal and post-feudal eras, and European consciousness). When traditional notions of international law have not supported the idea of western hegemony, western scholars have not hesitated to turn the viewpoints of their governments into academic reasoning, as exemplified by the realist theory. See Shirley V. Scott, "International Law as Ideology: Theorizing the Relationship between International Law and International Politics” (1994) 5 E.J.I.L. 313. 
the meaning of independence after the long, dark period of colonialism and western dominance.

Nevertheless, there have been a few efforts that have projected the practice of international law into non-European regions, albeit with different origins and results. ${ }^{2}$ Such efforts impact how international law has been recognized with respect to its origin and development. The geopolitical map of the world has changed tremendously as a result of decolonization, the cold-war era, the post cold-war era, and the post-9/11 era. Modern concepts of democracy and governance have been installed pursuant to the concept of the rule of law in countries both rich and poor, or so-called "civilized" or "non-civilized" nations. But the rule of law is a complex system due to its abuses. For instance, in a dictatorial system of governance, the rule of law is asserted with the help of the military or police force to make a system of law that is strong and respected. ${ }^{3}$ States justifying various action do not hesitate to assert their respect for their interpretations of law in order to lead the international community to believe that the international rule of law has been practiced. This approach is particularly popular among powerful countries and realists, who suggest that the idea of international law is integral to the international distribution of power to sustain political order on an international level. To realists, international law is no more than an accepted tool used by international actors as a basis for interaction. ${ }^{4}$

Within this framework of conflicting views regarding the use and interpretation of international law, ${ }^{5}$ the international community once tried to address the root cause of international problems - the underdeveloped state of societies - by recognizing a right to development. The notion of the right to development was first conceived by the United Nations in 1986 with the adoption of the Declaration on the Right to Development, ${ }^{6}$ which defined the

A few scholars struggle to bring non-western notions of international law into the mainstream international law debate. See Antony Anghie, "Finding the Peripheries: Sovereignty and Colonialism in Nineteenth-Century International Law" (1999) 40 Harv. Int'l L.J. 1. Anghie, while discussing naturalists and positivists, says the "non-European world was excluded from international law..." (at 29). According to Anghie, the naturalists and positivists "distinguish(ed) the civilized from the uncivilized (world)" by "asserting the fact that while certain societies may have had their own systems of law these were of such an alien character that no proper legal relations could develop between European and non-European states...the problem of the legal personality of non-European peoples could be most simply resolved by the actual act of colonization” (ibid.). See also Antony Anghie, “Colonialism and the Birth of International Institutions: Sovereignty, Economy, and the Mandate System of the League of Nations” (2002) 34 N.Y.U.J. Int'l L. \& Pol. 513; R.P. Anand, “Attitude of the Asian-African States Toward Certain Problems of International Law" in Frederick E. Snyder \& Surakiart Sathirathai, eds., Third World Attitudes Toward International Law: An Introduction (Boston: Martinus Nijhoff, 1987) 23. Anand, while discussing how the scope of international law in the European context is limited to rules of war and peace, traces non-European approaches to international law in places such as China, the South Asian continent (Bhutan, Sri Lanka, Nepal, Pakistan, India, Maldives, Bangladesh, and Afghanistan), Egypt, and Assyria. He claims that international law governing treaties, rights of asylum, treatment of aliens and foreign nationals, immunities and privileges of ambassadors and modes of acquiring territories, as well as the law of the sea and the maritime belt, are well developed in those regions.

3 J.L. Brierly, The Law of Nations: An Introduction to the International Law of Peace, 6th ed., Humphrey Waldock, ed. (Oxford: Clarendon Press, 1963).

$4 \quad$ Scott, supra note 1 at 324-25.

5 That is, conflicting views among realists, positivists, and naturalists; between powerful and powerless nations; between the North and the South.

$6 \quad$ GA RES 41/128, UN GAOR, 41st Sess., Supp. No. 53, UN Doc. A/41/53 (1986) 186 [Right to Development]. 
meaning of development ${ }^{7}$ and highlighted the major obstacles of development: colonialism, neo-colonialism, apartheid, all forms of racism and racial discrimination, foreign domination and occupation, aggression and threats against national sovereignty, national unity and territorial integrity, and threats of war. ${ }^{8}$ Before the right to development was recognized, the UN had endorsed the New International Economic Order ${ }^{9}$ (NIEO), stating that among the duties of all countries is the "[e]xtension of active assistance to developing countries by the whole international community, free of any political or military conditions." 10 This declaration, the result of collective activism of the countries of the South, was one of the catalysts for the recognition of a right to development. ${ }^{11}$ Unfortunately, the possibility inherent in a North-South discussion failed when the United States declared the death of the NIEO. ${ }^{12}$ The idea of development with redistribution of knowledge and wealth through the NIEO disappeared only to be reintroduced when the right to development was declared by the UN and became a part of and challenge to international law. Although non-binding rhetoric, this declaration remains a part of international law. The concept of the right to development transformed from the notion of action oriented North-South cooperation under the NIEO to a third-generation human rights approach. ${ }^{13}$ Now the concept of the right to development has been replaced by a focus

UN GAOR, 41 Sess., Annex, Agenda Item 101, UN Doc. A/RES/41/53 (1986) 186 at Preamble, para. 2:"[D]evelopment is a comprehensive economic, social, cultural and political process, which aims at the constant improvement of the well-being of the entire population and of all individuals on the basis of their active, free and meaningful participation in development and in the fair distribution of benefits resulting therefrom.”

Ibid. at Preamble, para. 9.

The initiative for the NIEO was launched in 1973 at the Conference of Non-Aligned Countries held in Algiers. This economic order was proposed by the developing countries during the Non-Aligned Movement conference as a first comprehensive vision of world problems and their economic solutions. Later in 1974, the UN General Assembly adopted the resolution on the establishment of a NIEO. The resolution is based on the recognition of the inequalities among countries in the North and the South; it reiterates the sovereignty of the states over their natural resources and economic activities and enumerates a set of demands of developing countries in the areas of international trade, financial assistance, monetary reforms, technology transfer, etc., while denouncing colonialism, neo-colonialism, and other forms of oppression faced by developing countries. See Declaration on the Establishment of a New International Economic Order, GA Res. 3201 (S-VI), UN GAOR, 6th Spec. Sess., Supp. No. 1, UN Doc. A/9559 (1974) 3 [NIEO Declaration].

Ibid., Principle 4(k).

11 Other catalysts include the Charter of the United Nations, 26 June 1945, Can. T.S. 1945 No. 7 , art. 76 [UN Charter]. Article 76 contemplates the development toward self-government as well as the International Covenant on Economic, Social and Cultural Rights, 16 December 1966, 993 U.N.T.S. 3, 6 I.L.M. 360 (entered into force 3 January 1976). Similarly, the Charter of Economic Rights and Duties of States, GA Res. 3281 (XXIX), UN GAOR, 29th Sess., Supp. No. 31, UN Doc. A/9631 (1975) 50 at 50, 52 [Charter of Economic Rights] reiterates these principles. The Charter of Economic Rights, a nonbinding document, provides 15 principles to which states were to adhere, including the right to control their natural resources, the right to regulate economic activities, and the North's duty not to interfere with these rights.

12 The Brandt Commission was created to continue to bridge the gap between the North and the South. See North-South: A Programme for Survival: Report of the Independent Commission on International Development Issues (Cambridge, Mass.: MIT, 1980). However, the Commission did not survive long enough to cement progress because U.S. President Reagan declared the death of the NIEO Declaration in 1981. As a result, the Association of Southeast Asian Nations was formed and focus was diverted: high level-developing countries started focusing on their own international agenda rather than on the common agenda of the South. But see Adam Snyed, "Globalization \& Autonomy Glossary - NorthSouth,” online: McMaster University <http://anscombe.mcmaster.ca/global1/servlet/Glossarypdf?id= CO.0063>.

13 First-generation rights are civil and political rights; second-generation rights are social, economic, and cultural rights; and third-generation rights include the right to development and environmental rights. 
on international trade and the notion of the environment-guided concept of sustainable development.

\section{TRADE AND DEVELOPMENT}

Liberalized trade is not new, but it became an organized concept through trade agreements designed to address geopolitical conflict on the international plane. Common economic interest was viewed as a tool to avoid armed conflict, as is evident from the creation of the European Community during the post-World War II era. One principle underlying the creation of the World Trade Organization (WTO) ${ }^{14}$ is arguably the promotion of international geopolitical stability. ${ }^{15}$ The WTO is a reincarnation of the General Agreement on Tariffs and Trade, ${ }^{16}$ which was first created by 23 countries, and has been regarded as an exclusive trade club benefiting a limited number of countries. ${ }^{17}$ Now there are 150 member countries in the WTO. ${ }^{18}$ When the GATT was created, many developing countries were colonized or oppressed. In contrast, in 1994, when the WTO was negotiated, those colonized or oppressed countries had become independent and aware of global affairs. All of the developing countries that are members of the WTO are hopeful that the WTO will bring about higher standards of living for the billions of people in those countries who are living on less than a dollar a day, and reduce, if not eliminate, economic inequality among nations. Developing and underdeveloped countries considered International Liberalized Trade (ILT) to be a vehicle of development. Unfortunately, the practice of ILT has not departed from its core orthodox concept of maximization of corporate benefits through the free market system. Further, the WTO has not taken action to regulate and reinforce the social and economic agenda of developing and underdeveloped countries. As a result, liberalized trade under the WTO has not benefited poor countries, but rather has become an instrument to maintain the hegemony of powerful countries, and a device by which they control the world agenda. ${ }^{19}$ Despite disparity among

Agreement Establishing the World Trade Organization, 15 April 1994, 1867 U.N.T.S. 154, 33 I.L.M. 1144 (entered into force 1 January 1995) [WTO Agreement].

15 The creation of the European Community contributed to resolve the differences between France and Germany through common steel and coal markets. Similarly, the WTO can be viewed as a tool to resolve the differences among nations in the world. There are more than 350 cases between countries that have been resolved through the WTO dispute settlement system. See WTO, "Dispute Settlement: Chronological List of Disputes," online: WTO <http://www.wto.org/english/tratop_e/dispu_e/ dispu_status_e.htm>.

1630 October 1947, 58 U.N.T.S. 187, Can. T.S. 1947 No. 27 (entered into force 1 January 1948) [GATT 1947], including the General Agreement on Tariffs and Trade 1994, Annex 1A, WTO Agreement, supra note 14 [GATT 1994], collectively referred to as the GATT.

17 Following World War II, allied nations created new institutions that would avoid the causes of war. Those institutions were the World Bank, International Monetary Fund (IMF) and the International Trade Organization (ITO) - known as Britton Woods Institutions. Due to U.S. opposition to the ITO, its provisional agreement, the GATT, became the agreement to serve the interests of member countries relating to commodity, restrictive business practices, employment, international investment, etc. The intention of this agreement was to provide economic aid for reconstruction of post-war Europe and monetary issues. Many countries at that time were still colonized and their economic interests were mute. Therefore, it may be regarded as exclusive trade club of limited number of countries. WTO, "Understanding the WTO: Members and Observers," online: WTO <http://www.wto.org/ english/thewto_e/whatis_e/tif_e/org6_e.htm>.

19 The WTO has been challenged by different civil groups from around the world for its use of "unofficial" and exclusive mini-ministerial Green Room meetings. Participation in these meetings is by invitation only, and includes about 25 countries, yet they discuss critical WTO matters affecting all member states. Such exclusionary Green Room meetings are used to build consensus among the few which is then 
nations, market conditions, and the flow of artificial capital, ${ }^{20}$ the world already has embraced the universal truth of the value of a free market and globalization, thanks to the concept of liberalized trade. Reduction in the market economy can be proscribed as harmful to the economy and antagonistic to democracy. Therefore, developing and underdeveloped countries are pressured to accept the compelling nature of trade investment and competition. At the same time, due to Green Room meeting practices, the Green Room countries have been able to make the WTO their economic and political nest, whereas the concerns of underdeveloped are benignly, if not hostilely, neglected.

However, the WTO has not dropped the idea of development; in its trade rules, it supports the concept of sustainable development as one of its objectives. ${ }^{21}$ Trade promotes important aspects of economic development, including trade-related technology transfer, access to new products and product ideas, competition on the global market, and comparative advantage. The international community uses trade concepts to support the idea of development. Although the Bretton Woods agreement ${ }^{22}$ and the GATT were created to meet the problems faced by a few developed countries during the 1930s, ${ }^{23}$ they have always claimed to be effective instruments to bring development to the underdeveloped world. However, efforts have been made in these institutions to realize the idea of development. One such effort is the creation of the United Nations Conference on Trade and Development (UNCTAD), ${ }^{24}$ which was created to make a shift from import substitution and reliance on foreign aid to increasing exports and trade by developing countries. ${ }^{25}$ The overall concept of development, as perceived by the WTO, is that the pursuit of economic growth will bring development and will reduce the absolute poverty in underdeveloped countries. ${ }^{26}$ Existing negotiation processes that favour more powerful nations have generated mistrust among developing nations in the system of international behaviour and transactions. Among other deeply rooted factors, important factors weighing the

presented to the majority as a take-it-or-leave-it package. It is clearly an undemocratic practice and in violation of the one-country, one-vote policy and the consensus system of the WTO. For more information on Green Room meetings, see "NGOs Call on Trade Ministers to Reject Exclusive MiniMinisterial and Green Room Meetings in the Run-Up to, and at the 5th WTO Ministerial Conference," online: Center for International Environmental Law < http://www.ciel.org/Tae/WTO_5Min_112002. html>.

One example of the flow of artificial capital is credit economy, which is based on expected and anticipated financial capacity and the condition that underdeveloped countries can hardly compete. Supra note 14 at Preamble.

United Nations Monetary and Financial Conference, held in Britton Woods, New Hampshire, 1-22 July 1944. The conference reached an agreement to establish a post-war international monetary system of convertible currencies, fixed exchange rates and free trade known as the Britton Woods Agreement. To achieve these objectives, the agreement created the IMF and the International Bank for Reconstruction and Development (in the World Bank). This agreement had also proposed to create the ITO, but failed to due to the U.S. opposition. Instead, the ITO's provisional agreement, the GATT, was adopted.

Gerald M. Meier, “Aid Through Trade Proposals: Some Criticisms” (1967) 2 International Society of Stanford Law School Proceeding 98 at 99.

See online: UNCTAD <http://www.unctad.org/>.

This can be viewed as a shift in the international economic system because as economists have formerly argued that international trade was operated as mechanism of international inequality. See Meier, supra note 23 .

The WTO was established on the basis of a consensus system and the anticipation that free trade and consistent regulatory policies on the part of the WTO would deliver unquestionable advantages, particularly to the developing countries. However, the historic Marrakesh meeting did not address economic, political, institutional, and social inequality among nations, all of which have made it impossible to transcend the orthodox approach of hegemonic style in the international trade system. 
scales in favour of developed countries are existing infrastructure of a nation and its capacity to trade internationally, the state resources and cost of institutional structures supporting a country's economic order and competitiveness, and political inequality among nations. ${ }^{27}$ In such a situation, development remains only a dream and the hegemonic style of the WTO system becomes the reality. One reality of the WTO is that free trade is not possible due to other pressing concerns in the international arena, such as health, the environment, and sustainable development. ${ }^{28}$

The idea of sustainable development was initially incorporated into WTO rules and decision making ${ }^{29}$ because it was essential to maintaining the WTO's functional legitimacy. ${ }^{30}$ Now it has become a core component of all international legal approaches and one of the functional missions of all international organizations. Unfortunately, the international community jumped into the concept of sustainable development with no transition in meaning or implementation from the historical concept of development as reflected in the UN's right to development and in the NIEO. The concept of sustainable development suffers from lack of a precise meaning. ${ }^{31}$ Is it a substitute for the concept of development — do we no longer deal with development but only sustainable development? The trade rules as prescribed by the WTO/GATT, though member-driven, are directed toward the interests of the traders, not toward the interests of members. The nature and transaction of trade under the WTO trade regime gives priority to

Factors relating to international trade that have contributed skepticism about the existing WTO system have been discussed by various authors. See Frank J. Garcia, Trade, Inequality, and Justice: Toward a Liberal Theory of Just Trade (Ardsley, N.Y.: Transnational Publishers, 2003) at 23. The author suggests some factors as characteristics of small economies in the international trading system: small size of population and territory, Gross Domestic Product, dependence on external trade, high level of imports, dependences on trade taxes, limited human resources and technical expertise, undiversified economic base, etc. See also Welber Barral et al., "Trade and Development(s): Many Concepts Different Approaches: How to Make the Doha Round a Genuine 'Development' Round,” Proceedings of the One Hundredth Annual Meeting of the American Society of International Law (2006) 100 American Society of International Law Proceedings 217 at 217-20. See the art. XX exceptions of the GATT, adopted in the GATT 1994, supra note 16, art. xx. One of the objectives of the WTO is sustainable development as prescribed in its Preamble, which refers in part to "optimal use of the world's resources in accordance with the objective of sustainable development”: supra note 14. Similarly, the WTO Appellate Body has interpreted GATT 1994, art. XX in a manner consistent with the objectives of sustainable development, recognizing that it is no longer possible for the WTO to promote the free-trade goals of the GATT (such as promoting market access) above all other concerns, for example health and environment, and the objectives of sustainable development. See United States — Import Prohibition of Certain Shrimp and Shrimp Products (1998), WTO Doc. WT/DS58/AB/R (Appellate Body Report), online: WTO <http://docsonline.wto.org/ gen_search.asp>. See also United States - Standards for Conventional and Reformulated Gasoline (1996), WTO Doc. WT/DS2/AB/R (Appellate Body Report), online: WTO <http://docsonline.wto.org/ gen_search.asp>.

When the WTO was negotiated, unlike the GATT 1947, many developing nations, which represented most of the world's population, participated, so ignoring the term development could have been fatal to the success of the negotiations. The WTO has been characterized as a grand bargain between the North and the South. See Sylvia Ostry, "The Uruguay Round North-South Grand Bargain: Implications for Future Negotiations” in Daniel L.M Kennedy \& James D. Southwick, eds., The Political Economy of International Trade Law: Essays in Honour of Robert E. Hudec (Cambridge: Cambridge University Press, 2002) 285.

31 Ved P. Nanda, "Sustainable Development, International Trade and the Doha Agenda for Development" (2005) 8 Chapman L. Rev. 53. The author discusses the history and relevance of sustainable development. 
individual traders; ${ }^{32}$ the benefits and success of member countries within the WTO are achieved through the "improved conditions for these private operators"33 (individual traders). The WTO has focused on an "enlightened mercantilist" 34 approach where trade expansion is obvious and development is nebulous, since development can be achieved only after trade and business interests are satisfied. The Banana case is an example of the tension between trade interests and development interests of the African, Caribbean and Pacific group (ACP) countries and how governments support the trade interests of corporations where they conflict with the needs or development interests of developing and underdeveloped countries. ${ }^{35}$ Robert Howse strongly argues that the WTO is only for the trade people and the trade rules - it is not concerned with human rights and development issues. ${ }^{36}$

The WTO is yet another forum like the World Bank ${ }^{37}$ and the Organization for Economic Cooperation and Development (OECD), ${ }^{38}$ where developed countries discuss what they could do for developing and underdeveloped countries and what priorities should be set for their expectations in terms of international development and a humanitarian agenda. Empowerment of deprived people in poor countries is not the goal of the WTO: its principal goal is trade liberalization. To achieve this goal, the WTO offers each of its members the opportunity to participate in market competition, ${ }^{39}$ on its face fair and free, but in reality, something quite

32 See United States - Sections 301-310 of the Trade Act of 1974 (Complaint by the European Communities) (1999), WTO Doc. WT/DS152/R (Panel Report), online: WTO <http://docsonline. wto.org/gen_search/asp> at para. 7.76. The panel discusses the expectations of the WTO and states that the WTO is designed to provide security and predictability for the multilateral trading system, which is composed "not only of states but also, indeed mostly, of individual economic operators." Ibid. at para. 7.77 .

34 See Kyle Bagwell \& Robert W. Staiger, The Economics of the World Trading System (Cambridge, Mass.: MIT Press, 2002) at 60-61, xi-xii. The authors accuse the GATT/WTO of representing non-state parties. The authors highlight that the reason for lowering the tariff is nothing more than value of market access as seen or evaluated by the private exporters somewhere in the world. As a result, the authors claim, governments show their willingness to accommodate something of value to that government from which the exporters operate.

35 In the WTO Banana case, the U.S. had no bananas to export, yet sponsored Chiquita and Dole, representing their interests in the WTO Dispute Settlement Body. As a result, ACP countries lost their benefits due to mutual arrangements between the European Union and ACP countries. See European Communities - Regime for the Importation, Sale and Distribution of Bananas (Complaint by the United States) (1998), WTO Doc. WT/DS27/15R (Panel Report), online: WTO < http://docsonline.wto. org/gen_search/asp>.

36 Robert Howse, "Mainstreaming the Right to Development into International Trade Law and Policy at the World Trade Organization” (Paper prepared for the Office of the UN High Commissioner for Human Rights, High Level Seminar on the Right to Development, Geneva, Switzerland, 9-10 February 2004) in Mainstreaming the Right to Development into International Trade Law and Policy at the World Trade Organization: Note by the Secretariat, Supp. No. 2, UN Doc. E/CN.4/2/2004/17 (2004) 3 at para. 20, quoting, Peter Sutherland: "the 'watertight compartments' view of the WTO remains influential in trade policy circles. One former GATT Director-General ... wrote ... 'the WTO is not an aid agency.' Or, as the WTO Singapore Ministerial Declaration of 1996 suggested, the ILO is the competent body for labour issues. Human rights impacts of trade laws and policies are something to be addressed outside the WTO — 'we' do the 'trade', they do the 'human rights.'” The World Bank Group, “The World Bank,” online: The World Bank <http://www.worldbank.org>. OECD, "Home,” online: OECD <http://www.oecd.org/home/>.

The competition policy of the WTO is one of the "Singapore Issues." See WTO, Singapore Ministerial Declaration WTO Doc. WT/MIN(96)/DEC (13 December 1996), online: WTO < http://192.91.247.23/ english/thewto_e/minist_e/min96_e/singapore_declaration96_e.pdf $>$. In the period up to the 2003 Ministerial Conference, the working group was instructed to focus on, among other matters, clarifying the case for progressive reinforcement of competition institutions in developing countries through 
different because the members are not on equal footing. For this reason, the opportunities promoted by the WTO have not helped much in bringing development to many Asian and African countries. Despite its broad membership, the true stakeholders in the WTO system are the privileged corporations and developed countries that have found the international trading system a useful tool for promoting their own interests, not the development of poor countries or the empowerment of the deprived people in those societies.

The shift from a recognized right to development to the concept of sustainable development is a convenient strategy to bolster the WTO's support of the international status quo where no equitable concept provides legitimacy. If we are to realize a right to development and the objectives of the NIEO, the WTO system as it stands now requires change through some kind of intervention in international economic relations. Such intervention would require developed countries to accept restraints in their treaty-making style to make room for a right to development that allows poor countries to diminish the gap between themselves and established international powers. If, however unlikely, such a right of underdeveloped countries is established, it must not only create expectations in underdeveloped countries but also provide a legal framework for enforcement. Such a drastic change in the WTO regime that benefits underdeveloped countries as a right ${ }^{40}$ would require changes in existing legal and institutional frameworks and practice. It would also require the WTO to stop paying lip service and start paying attention to development. The WTO claims that the trade regime is designed to promote development and that the WTO cares about the living conditions of humans in the world by promoting aid for trade, ${ }^{41}$ but existing factors work against even the concept of free trade as envisioned by the WTO regime. Ultimately, the proactive development agenda within the WTO regime is a daydream. Agricultural protectionism, which among the developed world has been a well accepted norm, poor implementation of the Agreement on Agriculture, ${ }^{42}$ dirty tariff practices, and subsidies are the main reasons that the Doha Development Agenda (DDA) failed and are also proof that developed countries and the WTO are not serious about the real development of the underdeveloped countries. One may easily assume that the WTO has turned to the concept of sustainable development into an instrument to legitimize the WTO regime by keeping up the appearance of a development agenda without actually focusing on development.

capacity building. This was intended to better position developing countries to evaluate the implications of closer multilateral cooperation on various developmental objectives. However, this subject has been removed from the Doha Agenda. For more about the WTO’s Doha Round, see International Institute for Sustainable Development (IISD), “Doha Round Briefing Series,” online: IISD <http://www.iisd.org/ trade/wto/doha_briefing.asp>.

40 This kind of right has been characterized as a meta-right, that is, a right pursuant to which policy is directed toward providing benefits (in this case, benefits to the unprivileged in order to realize the right to development), but with no guarantee of a legal mechanism to enforce the right. See Amartya K. Sen, “The Right not to be Hungry” in Philip Alston \& Katarina Tomaševski, eds., The Right to Food (Boston: M. Nijhoff, 1984) 69.

41 Doha Ministerial Declaration, 14 November 2001, 41 I.L.M. 746. This is the outcome of the fourth ministerial conference in Doha, Qatar in 2001. In this conference, WTO members agreed to work on new negotiations on different issues, collectively known as the "Work Program.” Among these issues were agriculture, services, market access for non-agricultural products, trade-related aspects of intellectual property rights, trade and investment, trade and environment, trade and transfer of technology, etc. An agreement on the DDA has not been reached even after the Cancun (2003), Geneva (2004), and Hong Kong (2005) Ministerial Conferences.

$42 \quad$ Annex 1A, WTO Agreement, supra note 14. 


\section{ENVIRONMENT AND DEVELOPMENT}

Just as the trade regime of the WTO has included the concept of sustainable development in its agenda, the Multilateral Environmental Agreements (MEA) have also inserted the concept of sustainable development into its treaty regimes. The first historic MEA, the Stockholm Conference, ${ }^{43}$ focused not on the concept of development, but rather on the core agenda of environmental protection at the international level. ${ }^{44}$ Only later, in 1980 , was the concept of sustainable development brought forth in the World Conservation Strategy. ${ }^{45}$ Although the concept was defined in the work of the World Commission on Environment and Development, ${ }^{46}$ that definition of sustainable development did not gain legal force. In 1989 , the United Nations Environment Program(UNEP) elaborated on its meaning, focusing on national and international equity, supportive international economic conditions, and international cooperation. ${ }^{47}$ The concept of sustainable development was still in its trial phase. Later in 1992, during the United Nations Conference on Environment and Development (UNCED), ${ }^{48}$ sustainable development was heavily discussed and put on the agenda in order to provide a fresh start to examining the concept. The Rio Declaration considered a new paradigm for sustainable development, ${ }^{49}$ linking the environment and sustainable development. In formulating the concept, the developed countries were more concerned about protection of the

43 The Stockholm Conference on the Human Environment was held in Stockholm, Sweden from 5-16 June, and a declaration was produced: Declaration of the United Nations Conference on the Human Environment, 16 June 1972, UN Doc. A/Conf.48/14/Rev.1 (1973), 11 I.L.M. 1416 [Stockholm Declaration]. In addition to producing the the Stockholm Declaration, the conference also created the Stockholm Action Plan and the United Nations Environment Programme (UNEP), including the related environment fund. For more information on the Stockholm Action Plan, see “Action Plan,” online: UNEP <http://www.unep.org/Documents.Multilingual/Default.asp?DocumentID=97>. For more information on the UNEP, see online: UNEP <http://unep.org $>$.

44 Principles 1 and 21 of the Stockholm Declaration, ibid., focus more on safeguarding environmental quality to provide dignity of human life for present and future generations (the right to a healthy environment) and the sovereign right of a country to exploit its own natural resources as customary international law.

45 The World Conservation Strategy is published by the Union for Conservation of Natural Resources (IUCN). The strategy is a joint product of the IUCN, the World Wildlife Fund, and the UNEP. For more information see online: OECD <http://stats.oecd.org/glossary/detail.asp?ID=2941>.

46 World Commission on Environment and Development, Our Common Future: Environmental Protection and Sustainable Development: Legal Principles and Recommendations (Oxford: Oxford University Press, 1987) (chair: Gro Harlem Brundtland). The Commission defined sustainable development as "development that meets the needs of the present without compromising the ability of future generations to meet their own needs" (at 43).

47 UNEP, Report of the Governing Council on the Work of its Fiftieth Session, UN GAOR 44th Sess., Supp. No. 25, UN Doc. A/4425 (1989) 153.

48 The UNECD, also known as the Rio Summit or Earth Summit, was held in 1992 in Rio de Janeiro, according to the mandate of the General Assembly resolution: see United Nations Conference on Environment and Development, GA Res. 44/228, UN GAOR, 44th Sess., Supp. No. 49, UN Doc. A/44/49 (1989) 151. This conference produced two treaties: the United Nations Framework Convention on Climate Change, 9 May 1992, 1771 U.N.T.S. 107, 31 I.L.M 849 (entered into force 21 March 1994) and the Convention on Biological Diversity, 5 June 1992, 1760 U.N.T.S. 79, 31 I.L.M. 818 (entered into force 29 December 1993). As well, the conference produced the One Forest Principles: Non-Legally Binding Authorative Statement of Principles for a Global Consensus on the Management, Conservation and Sustainable Development of all Types of Forests, 13 June 1992, 31 I.L.M. 882; the Rio Declaration on Environment and Development, 14 June 1992, 31 I.L.M. 874 [Rio Declaration]; and UNECD Agenda 21: Programme of Action for Sustainable Development (New York: UN Department of Public Information, 1992) at 13 [Agenda 21]). Nanda, supra note 31 at 53. 
environment and the developing countries were more concerned about development. As a result of negotiations and the resulting bargain struck between the two worlds, the Rio Declaration produced 27 principles, ${ }^{50}$ and copied the environmental protection priority of Principle 21 of the Stockholm Declaration. ${ }^{51}$ The Rio Declaration also addressed the concept of development by inserting the principle of intra- and inter-generational equity stating, "[t]he right to development must be fulfilled so as to equitably meet developmental and environmental needs of present and future generations."52 The Rio Declaration outlined the central concerns raised in recognizing an environmental-development nexus, such as the health and integrity of the Earth's ecosystem; ${ }^{53}$ common but differentiated responsibilities according to the level of contributions to global environmental degradation; ${ }^{54}$ special priority to the needs of the developing countries, particularly the least developed and those most environmentally vulnerable ${ }^{55}$ healthy and productive lifestyles in harmony with nature, ${ }^{56}$ reduction of unsustainable patterns of production and consumption; ${ }^{57}$ the precautionary principle; ${ }^{58}$ the polluter pays principle $;^{59}$ environmental impact assessment as a national instrument for development activities; ${ }^{60}$ and a notification and consultation process among affected nations in the event of disasters and emergencies that are likely to produce harmful environment effects. $^{61}$

The Rio Declaration failed to detail how the right to development would be achieved. It only urges nations, key sectors of societies, and people that the right to development must be fulfilled so as to "equitably meet developmental and environmental needs of present and future generations." ${ }^{2}$ Whose generation needs are to be met - those of the developed countries or those of the least developed countries? How are underdeveloped countries to be assessed to see whether their developmental and environmental needs for the present generation have been met? In addition to these omissions, the Rio Declaration tends to tilt more towards future generations than towards the developmental and environmental problems of present generations of the underdeveloped world. Is the Rio Declaration intended to acknowledge the right to development of future generations but not of present generations? The answer is cloudy. The concept of sustainable development was born from the tension between the developed and developing countries - the environment as perceived by the developed world and development as perceived by the developing world. The developed world has more negotiating (manipulating) capacity than the developing world due to established scientific, technical, financial, and knowledge bases. The doctrine of sustainable development has therefore become a convenient tool for the developed world to undermine the developing world's core demand of the right to development as conceptualized in the NIEO and the UN Declaration of the

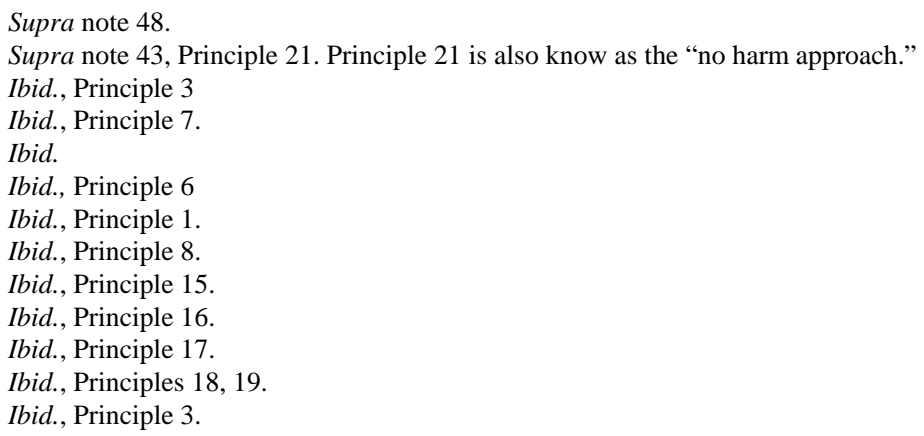


Right to Development. The right to development has been diluted within the mixed concept of environment and development — sustainable development — and the developed world can, at its discretion, decide when and what priority should be given to which element of the sustainable development amalgam, either the environment or development. By enfolding the development concern of the developing world within the concept of sustainable development, the compromise between the two worlds has earned legitimacy without any legal commitment to the development efforts of the developing countries.

The concept of sustainable development is furthered by the 500-page Agenda $21,{ }^{63}$ which is an "action plan” for implementation of the Rio Declaration. This action plan basically lays out the method of effectuating the concept of sustainable development, outlining issues regarding social and economic factors, ${ }^{64}$ conservation and resource management, ${ }^{65}$ public participation from different stakeholders, ${ }^{66}$ and implementation. ${ }^{67}$ To assist in implementing and overseeing the concept of sustainable development as prescribed by the Rio Declaration and Agenda 21, the UN General Assembly passed a resolution establishing the Commission on Sustainable Development (CSD) ${ }^{68}$ The goal of the CSD is to "advance global dialogue and foster partnerships for sustainable development." ${ }^{~} 69$ This sounds unimpeachable; however, the meaning of sustainable development is in fact controversial mainly because of political tension between the developed and underdeveloped world. The developed countries apply the concept in order to promote a sustainable environment and the developing world applies the concept in order to promote development. As long as the meaning of the concept remains controversial, the whole action agenda and the functions of the CSD cannot remain uncontroversial. For this reason, the concept of development has been claimed as a contestable concept. ${ }^{70}$

The developed countries can afford to implement the goal of sustainable development as laid out in Agenda 21 by creating their own national and local version of it. Financial, technological, and other infrastructure capacities allow the developed countries to implement the concept of sustainable development while satisfying environmental demands. The developing countries also will try to create national and local “Agenda 21s” (they must, if they want access to grants, loans, and assistance from the developed countries or from development institutions such as the World Bank), but they cannot implement the concept of sustainable

$63 \quad$ Supra note 48.

Ibid., s. 1.

Ibid., s. 2.

Ibid., s. 3.

Ibid., s. 4.

Report of the United Nations Conference on Environment and Development, GA Res. 47/190, UN GAOR, 47th Sess., Supp. No. 49, UN Doc. A/47/49 (1992) 141 at 142.

69 Program for the Further Implementation of Agenda 21, UN GAOR, 19th Spec. Sess., Annex 1, Agenda Item 8, U.N. Doc. A/RES/47/191 (1997) at c. 16. The CSD reviews the progress of the implementation of recommendations and commitments made in UNCED; provides policy guidance and options for activities to implement Agenda 21; promotes dialogues and builds partnerships among nations; and includes different interest groups such as women, non-governmental organizations (NGOs), indigenous peoples, businesses, farmers, scientists, and local authorities.

70 See Michael Jacobs, "Sustainable Development as a Contested Concept" in Andrew Dobson, ed., Fairness and Futurity: Essays on Environmental Sustainability and Social Justice (Oxford: Oxford University Press, 1999) 23. In this essay, the author discusses six core ideas that the term sustainable development embraces: environmental-economic integration, futurity, environmental protection, equity, quality of life, and participation. 
development because they lack the capacity to do so. First, underdeveloped countries are forced to implement the agenda of sustainable development with handouts and assistance. Second, underdeveloped countries will not be allowed to frame independent economic development agendas, as opposed to the developed countries, which first developed their economies by exploiting the world's resources through colonialism and oppression, and only then started discussing the environment. This has benefited the developed world in two ways. One, the ultimate economic benefit of natural resources can be locked in for the long-run in the name of sustainable development and inter-generational equity. Two, the present generation of the developed world is now aware that if the environment is not protected, their quality of life will be undermined. Therefore, the concept of sustainable development makes how a state manages its own domestic environment and resources a matter of international concern. ${ }^{71}$ Making sustainable development a subject of international concern or manipulation will definitely benefit the developed world, which in turn provides the financial and technological assistance to the developing world, particularly to the underdeveloped world in the form of charity.

The concept of the Earth as a single environmental entity and the people of the Earth as a single family has not been recognized, so real equity under law, which is embraced in the idea of the right to development, has been diminished by the concept of sustainable development. Under such conditions, sustainable development can be viewed not as development, but rather as a tool sustaining the lifestyles of those who already enjoy every material advantage, while maintaining on life support those living on a dollar a day who do not have even their basic needs met. If sustainable development inspires such a result, it will eliminate the concept of development and sustainable development as well.

Even the Millennium Development Goals (MDGs), a blueprint for building a better world in the 21 st century, ${ }^{72}$ transformed into an agenda for sustainable development. ${ }^{73}$ Jumping onto the sustainable development bandwagon, the World Summit on Sustainable Development (WSSD) $)^{74}$ also annexed the MDGs to its agenda. The summit focused, along with other issues,

Alan E. Boyle \& David Freestone, "Introduction" in Allan E. Boyle \& David Freestone, eds., International Law and Sustainable Development: Past Achievements and Future Challenges (Oxford: Oxford University Press, 1999) 6 at 6. The authors even claim that the concept of development has almost achieved an erga omnes (obligations to the international community as a whole) status.

72 The UN Millennium Summit was held from 6-8 September 2000, as mandated by the General Assembly. See Organization of the Millennium Summit of the United Nations, GA Res. 54/281, UN GAOR, 54th Sess., UN Doc. A/RES/54/281 (1999) and adopted the United Nations Millennium Declaration (New York: UN, Department of Public Information, 2000) [Millennium Declaration]. Components of the Millennium Declaration have since become known as the Millennium Development Goals: see UNDP, "About the MDGs: Basics," online: UNDP <http://www.undp.org/mdg/basics. shtml>. The MDGs comprise eight goals that are to be achieved by 2015 , which are: eradicate poverty and hunger; achieve universal primary education; promote gender equality and empower women; reduce child mortality; improve maternal health; combat HIV/AIDS; malaria and other diseases; ensure environmental sustainability; and develop a global partnership for development.

73 In his speech regarding the five-year progress report on the Millennium Declaration, UN SecretaryGeneral Kofi Annan stressed that "development must be sustainable": see "The Secretary-General Statement to the General Assembly” (21 March 2005), online: UN <http://www.un.org/largerfreedom/ sg-statement.pdf $>$ at 3 .

74 The WSSD, also known as the Johannesburg Summit, was held in Johannesburg, South Africa, from 26 August - 4 September 2002. The summit produced the following report: WSSD, Report of the World Summit on Sustainable Development (New York: UN, Department of Public Information, 2002), online: Johannesburg Summit $2002<$ http://www.un.org/jsummit/html/documents/summit_docs.html $>$ [Report 
on the eradication of poverty and unsustainable patterns of consumption and production. ${ }^{75}$ As with previous efforts, this time the path of sustainable development was also widely endorsed, without consideration of the previous route laid down by the right to development. Now the world, particularly the developing and underdeveloped world, is far beyond the point where one could even dare to rethink the prospect and relevance of the concept of sustainable development as it has been configured. The idea of development has become a practice of asceticism for those countries. However, to deny the concept would be to endorse the principle of unsustainability ${ }^{76}$ and would be "an admission of our failure 'to address the key conceptual and methodological challenges","77 to providing a coherent framework so that the goals of sustainable development might be realized. ${ }^{78}$ Ved Nanda describes the concept of sustainable development as a central element of international discourse and states that its success depends upon the political will of, and concerted international effort by, the developed and developing countries, international organizations, and civil society. ${ }^{79}$

The concept of sustainable development as prescribed by the Rio Declaration and the Agenda 21 continues to gain momentum; it was discussed again in the 2002 World Summit on Sustainable Development in Johannesburg, South Africa. This summit focused on five areas of priority: water and sanitation, energy, health, agriculture, and biodiversity and ecosystem management (known as the WEHAB agenda). The Summit produced a declaration ${ }^{80}$ and the Plan of Implementation. ${ }^{81}$ This declaration, as other previous efforts, repeated the same old method of non-binding implementation initiatives as opposed to a binding commitment among nations through a formal agreement. Once again, it was another great success for those who like to avoid the idea of an independent right to development by championing the idea of sustainable development. Conferences from Stockholm to Johannesburg have been criticized for being meaningless in terms of their effectiveness aside from agglomeration of public awareness in the subject area, media hype, and increased participation. Such conferences also have been criticized as a being a waste of money; duplicative; diverting attention from real issues, such as the right to development of underdeveloped countries; placing political supremacy over difficult substantive issues, thus making less room for substantive progress; leading to compromises rather than commitments; and imposing the values of the less

of the World Summit]. This report contained a political declaration, which adopted the Johannesburg Declaration on Sustainable Development (at 1), and the Plan of Implementation of the World Summit on Sustainable Development (at 6) [Plan of Implementation]. This plan is not a set of principles, but rather a broader political approach to sustainable development. The Plan of Implementation is available online: UN Department of Social and Economic Affairs <http://www.un.org/esa/sustdev/documents/ WSSD_POI_PD/English/WSSD_PlanImpl.pdf $>$.

75 David Hunter, James Salzman \& Durwood Zaelke, International Environmental Law and Policy (New York: Foundation Press, 2007) at 209. Jude L. Fernando, “The Power of Unsustainable Development: What is to be Done?” (2003) 590 The Annals of the American Academy of Political Social Science 6 at 7, citing Ian Drummond \& Terry Marsden, The Conditions of Sustainability (New York: Routledge, 1999) at 2.

Fernando, ibid. at 8.

Ibid.

Nanda, supra note 31.

Report of the World Summit, supra note 74.

Plan of Implementation, supra note 74. Totaling 11 chapters, the Plan of Implementation addresses various issues, including poverty eradication, unsustainable patterns of consumption and production, sustainable development for Africa, the globalizing world and small island states, means of plan implementation, and an institutional framework. 
numerous developed countries over those of the underdeveloped countries. ${ }^{82}$ These criticisms are not very far from the truth. During the ten years from the Rio Conference to the Johannesburg Conference, environmental conditions worsened, poverty deepened, and implementation of sustainable development was disappointing. ${ }^{83}$ There are various reasons for these lacklustre results, one quite basic — a lack of conceptual clarity about sustainable development. Eyes are yet to open among nations and international organizations to the reality that development is a right and sustainable development is a practice style or discipline of that right. Instead, the concept of development has been tangled up with the concept of sustainable development, which in turn has been promoted loudly while shrinking to a political agenda rather than rising to a legal agenda.

\section{IS THERE ANY RIGHT TO DEVELOPMENT LEFT?}

Underdevelopment is a series of complex, interacting phenomena that result in inequalities of wealth; poverty; backwardness in terms of education, food, and health security; and economic, political, and technological dependence. Conversely, the concept of development would include equality; poverty eradication; advancement in education, food and health security; and economical, political, and technological independence rather interdependence. Therefore, development is the central answer to many of the world's most pressing problems. This is the only tool that lets people all over the world internalize a sense of equality and justice. While the price may be high to realize the concept of development, the stakes may be even higher.

Efforts to fashion a right to development have deep roots. The concept of a right to development in modern international law can be traced back to the Universal Declaration of Human Rights ${ }^{84}$ and the UN Charter. ${ }^{85}$ Since the adoption of the Declaration, there have been several references made regarding the right to development as a human right. The International Covenant on Civil and Political Rights ${ }^{86}$ and the International Covenant on Economic, Social and Cultural Rights ${ }^{87}$ were major efforts of the UN to realize universal human rights. Later, newly independent countries, formerly colonized and oppressed by the developed countries of the North, initiated a new agenda through the NIEO, based on the assertion that colonialism and

See Michael G. Schechter, “UN-sponsored world conferences in the 1990s” in Michael G. Schechter, ed., United Nations-sponsored World Conferences: Focus on Impact and Follow-up (New York: United Nations University Press, 2001) 3.

$83 \quad$ Nanda, supra note 31 at 62.

84 GA Res 217(III), UN GAOR, 3d Sess., Supp. No. 13, UN Doc. A/810 (1948), arts. 22, 25(1), 26 (1)-(2), 28 [Declaration].

85 Supra note 11. The UN Charter was signed on 26 June 1945 at the conclusion of the UN Conference on International Organization and came into force on 24 October 1945. Articles 55 and 76 of the UN Charter imply the concept of development. It may be noted that the right to development was not thought to be a priority when the UN Charter was created. When the UN Charter was signed, most of the developing countries were colonized and oppressed and the majority of the signatory countries were colonizing powers. Most of the colonized countries became independent, not as a result of the $U N$ Charter, but as the result of their own fight for independence. 
neo-colonialism were gross violations of international law ${ }^{88}$ that gave rise to economic and social rights. This concept was received by a few developed countries as a revolutionary concept that might require them to compromise their sovereignty in order to make a commitment to economic or development aid to the developing countries. However, the reality of underdevelopment and the resulting danger to world peace and security was recognized by all nations, and the General Assembly designated the 1960s as the United Nations Development Decade. ${ }^{89}$ Following the first UN International Conference on Human Rights in 1968 in Teheran, ${ }^{90}$ the General Assembly adopted the Declaration on Social Progress and Development $t^{91}$ on 11 December 1969. This declaration emphasized social progress through the continuous raising of the material and spiritual standards of living of all members of society. ${ }^{92}$ Later, the General Assembly adopted the Charter of Economic Rights. ${ }^{93}$ In 1977, the General Assembly adopted a resolution which stresses "the need for the promotion of the full dignity of the human person and the development and well-being of the society." 94 All of these efforts and instruments laid a foundation for the creation of a new right — the right to development.

Finally, in 1986, the General Assembly adopted the Right to Development, ${ }^{95}$ a non-binding international instrument and the first formal document to be adopted in the UN by consensus. ${ }^{96}$ Since then, the right to development has been a matter of historical, philosophical, legal, economic, and political debates. The term “development” is still oceanic. The transformation of the Right to Development into reality is still a daydream for those hundreds of millions of people who live on a dollar a day. For them, development is nothing but an empty promise.

Although the right to development has been recognized on paper through resolutions and by different international institutions, a legal foundation for the right to development has not been established. Instead, the right has lost its vigour in the process of being enfolded into the

Philip Alston, "Revitalising United Nations Work on Human Rights and Development" (1992) 18 Melbourne U.L. Rev. 216 at 218. According to the Alston, the position of the developing countries is that a right of development is a mandatory co-operation between the developed and developing countries where the imperialist world has a legally binding obligation to co-operate with the developing countries by transferring capital, technology, or other goods and services, and such transfers should be regarded as entitlements, not acts of welfare or charity. See First United Nations Development Decade, GA Res. 1710 (XVI), UN GAOR, 16th Sess., Supp. No. 17, UN Doc. A/5100 (1961) 17.

Proclamation of Teheran, Final Act of the International Conference on Human Rights, Teheran, 22 April - 13 May 1968, U.N. Doc. A/CONF.32/41 (1968) 3 [Teheran Proclamation]. GA Res. 2542 (XXIV), UN GAOR, 24th Sess., Supp. No. 30, UN Doc. A/7630 (1969) 49.

Ibid.

93 Supra note 11. While laying out the fundamentals of international economic relations, the Charter of Economic Rights affirmed that every state has the right "to freely exercise full permanent sovereignty" over its wealth and natural resources; to regulate "foreign investment within its national jurisdiction"; and "to nationalize, expropriate, or transfer the ownership of foreign property": see c. 2, arts. 2(a)-(c). It also provided that appropriate compensation should be paid "in cases of nationalization and that any controversies" shall be "settled under the domestic laws of the nationalizing State" and its tribunals unless all states concerned agree to "other peaceful means": see c. 2, art. 2(c). It also set forth the right of states "to associate in organizations of primary commodity producers in order to develop their national economies": see art. 5. effective enjoyment of human rights and fundamental freedoms, GA Res. 32/130, UN GAOR, 32nd Sess., Supp. No. 45, UN Doc. A/32/48 (1977) 150. Supra note 6.

96 The U.S. was the only country to vote against the Right to Development. 
concept of sustainable development. There is no consensus on the meaning of development and no serious effort to precisely define the right to development. Therefore, it has suffered from a lack of genuine international scrutiny. Overseeing the right to development is one of the functions of the UN Human Rights Council (UNHCR). ${ }^{97}$ Unfortunately, politics surrounding the issue has merely generated bundles of reports, which have led to no consensus about the practical consequences of the right to development. ${ }^{98}$ The political barriers are immense. During the cold war, the U.S. government had difficulty recognizing a right to development because of concerns that the right to development would promote the basic fundamentals of economic, social, and cultural rights at the expense of civil and political rights. ${ }^{99}$ The right to development is yet to recover from its brush with cold war mentality. Economic issues have contributed to the impotence of the UNHCR. The countries in the North have not been ready to commit to the transfer of economic and technological resources necessary to realize the right to development.

Nevertheless, sporadic efforts have contributed to the survival of the right to development. In 2002, the UN Conference on Financing for Development was held in Mexico. The goals of the conference were to adequately address growth, poverty eradication, and sustainable development. ${ }^{100}$ In order to realize the goals set by this conference, the resulting agreement stated that Official Development Assistance (ODA) to the least developed countries should be 0.15 to 0.20 percent of Gross National Product of developed countries as prescribed at the Third UN Conference on the Least Developed Countries. ${ }^{101}$ The Conference on Financing reiterated all of the concerns of the underdeveloped countries as described and unanimously adopted in the First, Second, and Third Conferences on Least Developed Countries. ${ }^{102}$ Other

The Commission addresses the issues of the right to self-determination; racism; the right to development; the question of the violation of human rights in the occupied Arab territories, including Palestine; the question of the violation of human rights and fundamental freedoms in any part of the world; economic, social, and cultural rights; civil and political rights, including the questions of torture and detention, disappearances and summary executions, freedom of expression, the independence of the judiciary, impunity and religious intolerance; the human rights of women, children, migrant workers, minorities, and displaced persons; indigenous issues; and the promotion and protection of human rights. The Commission also elaborates standards and implements those standards. See "UN Human Rights Council," online: Office of the UN High Commissioner for Human rights: <http://www. ohchr.org/english/bodies/hrcouncil/>.

See Henry J. Steiner \& Philip Alston, International Human Rights in Context: Law, Politics, Morals, 2d ed. (Oxford: Oxford University Press, 2000) at 1325. The U.S. voted against the Declaration on the Right to Development.

UN, Financing for Development, Monterrey Consensus of the International Conference on Financing for Development: Final Text of Agreements and Commitments Adopted at the International Conference on Financing for Development, Monterrey, Mexico, 18-22 March 2002 (New York: UN, 2002) [Conference on Financing]. This document deals with domestic savings, productive investment, and increasing human capacity of the developing and the underdeveloped countries. It also reaffirms international trade as an engine for development and committed to implement the outcome of the Doha round.

101 UN GA, Declaration: Third United Nations Conference on the Least Developed Countries, Brussels, Belgium, 14-20 May 2001, UN Doc. A/CONF.191/12 at 3 [mimeo. limited].

102 At the First UN Conference on the Least Developed Countries, held in Paris in 1981, as mandated by the General Assembly, guidelines were adopted for domestic actions by the least developed countries, which were to be complemented by international support measures. However, the unanimous commitment of the international community did not work well and as a result the development situation worsened during the 1980s. See United Nations Conference on the Least Developed Countries, GA Res. 34/203, UN GAOR 34th Sess., Supp. No. 46, UN Doc. A/34/46 (1980) 141. Again in 1990, the Second UN Conference on the Least Developed Countries was held in Paris as mandated by the GA. See Second 
follow-up meetings and summits have been held in order to effect the idea of development in the developing, particularly the underdeveloped, countries. ${ }^{103}$

All of these instruments are based on common precepts, such as: peace is dependent on development; hunger and poverty are rampant in underdeveloped societies; the present level of aid flow is insufficient to realize development goals; the international trade system is not fair and open; commitment to provide ODA has not been fully carried out by the developed world; the least developed countries are so overwhelmed by a lack of basic necessities that the governments of those countries like only to talk about development but do little or nothing; and there is a need for accountability by rich and poor countries in providing and receiving funds.

A serious question, then, arises: Why have all efforts of the international community and the administration of those efforts, either in a bilateral or in a multilateral way through international organizations, not trickled down to those poor and hungry people of the underdeveloped countries? In short, why are the least developed countries still the least developed countries? This question highlights the gap between the meaning and the reality of development. Although defined in the 1986 Declaration on the Right to Development, development remains an abstract concept. This abstract concept has yet to be realized by the fulfillment of basic economic needs of the poor; basic political components in governance such as democracy, rule of law and transparency; and basic social and political security as provided by the guarantee of civil, political, economic, social, and cultural rights. With the realization of these basic economic, social, and political components, both developing and underdeveloped countries can move forward on the path of development.

There is general consensus among nations on these basic elements of development, but the conditions that characterize underdevelopment still exist. There could be many reasons that the status quo remains entrenched despite many efforts and this consensus. This article addresses one such important reason - the lack of understanding of the societal attributes of underdeveloped countries. ${ }^{104}$ The core nature of a society lies in its cultural factors, such as its understanding of how things happen, rather than merely what happens; how decisions are

United Nations Conference on the Least Developed Countries, GA Res. 42/177, UN GAOR, 42nd Sess., Supp. No. 49, UN Doc A/42/49 (1987) 133. The outcome of the Conference was embodied in the Paris Declaration: see UN Conference on Trade and Development, Paris Declaration and Programme of Action for the Least Developed Countries for the 1990s (New York: UN, Department of Public Information, 1992). At this Conference, the international community committed itself to urgent and effective action, based on the principle of shared responsibility and strengthened partnership, to arrest and reverse the deterioration in the socio-economic situation in the least developed countries and to revitalize their growth and development. The program included the need for development to be humancentered, respect for human rights, observance of the rule of law, the need to improve and expand institutional capabilities and efficiency, and the importance of decentralization, democratization, and transparency at all levels of decision making.

103 Summit of World Leaders for the Action Against Hunger and Poverty (New York, 20 September 2004); Paris Declaration on Aid Effectiveness (Paris, 28 February - 2 March 2005); Declaration on Innovative Sources of Financing for Development (New York, 14 September 2005); Doha Meeting Financing Development to Achieve MDGs, Doha (Qatar, 17-18 June 2007). In addition to these multilateral efforts, the U.S. government created the Millennium Challenge Account in 2004 to create accountability for both rich and poor countries. For more information, see “The Millennium Challenge Account," online: The White House <http://www.white house.gov/infocus/developingnations/millennium.html>.

The understanding of the core nature of a society is the predominant factor to effecting progress in that society. 
made, rather than what decisions are made; the pressures that impact decision making and priority setting; and how members of the society (the stakeholders) determine the process. All of these factors comprise the core culture of a society. Such cultural phenomenon must be understood and treated as motivating factors in the thinking and thought processes of each individual member of a society and of a society as whole. Culture is the nervous system of a society, responding and reacting to a range of stimuli. The international community until now has considered only the visible face of development (basic material aspects and inspirational infrastructures), not the nervous system of development (the internal functioning of the society and its modus operandi in perceiving and realizing development or progress). Understanding the style of $\mathrm{Raj}^{105}$ (governance) is a difficult one. In every system of governance, social and cultural elements are deeply involved and are invisible to the bare eyes and misunderstood in a superficial viewing. Generally, they can be seen as an iceberg as they are at work in political practice. Therefore, understanding of the core nature of a society is an art of crafting and a Tantra (a geometric basis of connection of two - knowledge and nature, male and female for the purposes of this article, the North and the South). Unfortunately, the meaning of development, in general perception and practice, has been limited to the capacity of consumption and accumulation and does not incorporate cultural components. ${ }^{106}$

Another aspect of the failure of development efforts to date is the absence of a method to enforce the right to development. The absence of a right to enforcement is deliberate, with political and historical motivation. Historically, economic wealth has been used to establish strata ${ }^{107}$ such as those of slave and master. This use of economic wealth is still practiced today, with one difference: traditional society practiced this notion to create class hierarchies while modern society practices this notion to create hierarchies of individuals. No master, whether a class or an individual, wants to relinquish status until compelled to do so through transcendental spiritual realization, bloody revolution, or intervention of laws establishing a right to freedom from slavery. The power gained, not through the accumulation of wealth but through the poverty of others, is very important to understand in this respect. The needs of others, and the dependence that those needs foster, grant power to a person or a country in a position to respond. Therefore, differences in levels of economic development or wealth accumulation have made some states powerful and other states powerless, taking away the autonomy of poor countries because of their overwhelming needs and dependence on having those needs fulfilled. Defining development as a need or want, not as a right, may be seen as a deliberate move on the part of developed countries to maintain the status quo. Thus, economic assistance activities, whether aid or financing for development, are guided by the desire of the developed world to maintain status and power, and development is trapped in the political economy of power consciousness, and may (perhaps has?) become a burden for both rich and poor countries. For rich countries, development may be a burden because it will, if successful,

105 The term "Raj" is a word used as "statecraft" or system of governance in the classic literature of the Indus (Hindu) civilization in the South Asian continent, such as, Veda, Upanishads and Manusmriti. These texts are said to be written by great scholars at that time based on their memoirs and thoughts. The UN has moved towards integrating social and cultural elements into the concept of development by introducing the Human Development Index, which is used to measure progress toward development, but has been unable to connect its policies and programs to these social and cultural elements of developing societies. For more information, see “2006 Human Development Index Rankings,” online: UNDP <http://hdr.undp.org/en/statistics/>.

N. Umari, "Subsistence and Development” (1992) 2 Journal of Income Distribution 90. 
ultimately raze the foundation of status and power on which these societies are grounded. For poor countries, development may be a burden because they are loath to develop their societies on charity and under the conditions attached to this aid by developed countries and international development institutions. This is why one scholar calls development a "historically singular experience" ${ }^{108}$ and the reason that the type of development that is now on the table for discussion is tied to the ideas, expectations, and judgments of the developed countries. ${ }^{109}$ Frank J. Garcia aptly calls the right to development, in its current state, the political delivery of a basic bundle of rights, which are in reality not rights at all but a function of human charity. ${ }^{110}$ Sustainable development, either in trade-related activities or environmental-related planning, is a necessary tool of discipline to shape policy. However, it is a tool that cannot be useful until a substantive right to development is recognized. For this, the vested interests and language of power of developed countries and corporations alike must be discarded in favour of a language of justice that creates a legal right to development.

110 See Frank J. Garcia, “A ‘Fair’ Trade law of Nations or A ‘Fair' Global Law of Economic Relations?” (2007) 45 Alta. L. Rev. 303. 